\title{
Agenda Power in the Italian Chamber of Deputies, 1988-2000
}

\author{
by \\ Gary W. Cox \\ Department of Political Science \\ University of California, San Diego \\ William B. Heller \\ Department of Political Science \\ SUNY-Binghamton University \\ Mathew D. McCubbins \\ Department of Political Science \\ University of California, San Diego
}

\begin{abstract}
We find strong evidence that governing coalitions in Italy exercise significant negative agenda powers. First, governing parties have a roll rate that is nearly zero, and their roll rate is lower than opposition parties' roll rates, which average about $20 \%$ on all final passage votes. Second, we find that, controlling for distance from the floor median, opposition parties have higher roll rates than government parties. These results strongly suggest that governing parties in Italy are able to control the legislative agenda to their benefit. We also document significantly higher opposition roll rates on decree-conversion bills and budget bills that on ordinary bills consistent with our theoretical analysis of the differing procedures used in each case.
\end{abstract}


Traditional theories of responsible party government view the ability of party leaders to "whip" their members into line during legislative votes as the key to party government (e.g., Ranney 1962). Similarly, the traditional understanding of coalition government in many polities is that the leader of each participating party brings a certain bloc of disciplined votes to the coalition, in exchange for receiving cabinet portfolios and/or coalition support for key policies (e.g., Amorim Neto and Santos 2001). In these discipline-centric theories, the analytic focus is on plenary votes and the key to controlling legislative outcomes is the ability to reliably marshal a majority in such votes.

In contrast, Cox and McCubbins' procedural cartel theory (Cox and McCubbins 2005; 2006) highlights (a) the procedural powers that majorities worldwide tend to inherit or seize; and (b) how these procedural powers can help alleviate the difficulties of maintaining discipline within a diverse coalition. In their theory, parties and coalitions seek not just to control their members' plenary votes, when they can, but also to control the set of questions upon which those members are asked to vote in the first place-or, in other words, to control the plenary agenda. Controlling the agenda typically involves allocating special agenda-setting powers among the majority coalition's senior members, and then assuring their good behavior in using those powers.

The broadest claim of procedural cartel theory is that governing majorities in all democratic assemblies form agenda-setting cartels that distribute among their members a controlling share of the power to block bills from reaching the plenary agenda. A testable implication is that governing parties should almost never be rolled - that is, suffer the passage of a bill they oppose. The reason is that governing parties can foresee when they will suffer 
pivotal defections (and hence lose) on a given bill and use their blocking powers to prevent that bill from being considered in the first place.

A second claim of cartel theory is that oppositions vary in their procedural rights and, hence, their ability to delay or block the legislative progress of bills. This leads to a proposition that resonates with Blondel's (1973) general emphasis on the importance of delaying power: we expect the roll rates of opposition parties to vary inversely with their powers of delay. Unlike the literature taking its cue from Blondel, cartel theory thus provides a specific quantitative measure (i.e., the roll rate) that can be used to assess how much opposition blocking power matters, in terms of the relative frequency of bills enacted against the opposition's wishes.

In this paper, we examine agenda power in the Italian Chamber of Deputies from 1988 to 2000. This period includes the decline of the hegemonic Christian Democratic Party (DC) (already evident in the 1987 elections, more pronounced in the 1992 elections); the DC breakup (shortly before the 1994 elections); and the emergence of the new Italian party system, dominated by two large electoral cartels (induced by the new electoral laws) and characterized by substantial party switching by MPs. The profound changes in the party system make the time and place under study of great interest both generally and for the examination of agenda control in particular. Moreover, the variety of procedures that Italian governments can use-one for ordinary bills, another for decree-conversion bills, and so on-provides useful data with which to test cartel theory.

To test our theory, we calculate the roll rates of Italian parties when they are in government versus in opposition; and for ordinary bills versus bills to convert emergency decrees into law versus budget bills (we discuss the differences between these types of bill below). We expect that governing parties should have very low roll rates, for all three types of 
bill (ordinary, decree conversion, budget); and that opposition parties should have higher roll rates than governing parties on ordinary bills, with an even larger gap on conversion and budget bills (where the opposition has weaker blocking powers).

The paper proceeds as follows. In the next section we discuss agenda setting in the Italian Chamber of Deputies. In Section 2 we outline cartel theory and explain the predictions that derive from it. Section 3 describes the data we use to test our predictions. We present the results of our various tests of cartel theory in Section 4. Section 5 concludes.

\section{Agenda setting in the Italian Chamber of Deputies}

The prevailing view is that the agenda in the Italian Chamber of Deputies is set by a mixture of consensus and circumvention. The "consensus" part of the mixture refers to longstanding rules of procedure that endow many groups with vetoes (Allum 1973; Blondel 1988; Cotta 1990; Di Palma 1976; Furlong 1990; Hine 1993; Hine and Finocchi 1991; Manzella 1991; Spotts and Wieser 1986). For example, Rule 23 required unanimity from 1971 until 1997 and has since required a super-majority of three-fourths within the Conference of Group Chairpersons to place an ordinary bill onto the plenary agenda. The "circumvention" part of the mixture refers to a variety of techniques that Italian governments have used to circumvent the ordinary statutory process. First, delegations of decree and rule-making authority to the executive have increased substantially (Capano and Giuliani 2001; 2003). Such delegations avoid the statutory process entirely, except at the initial point of passing the delegating legislation. Second, rule changes have enhanced the government's ability to control the legislative process pertaining to three special types of bill: (1) bills to convert emergency decrees into law; (2) budgetary bills; and (3) bills ratifying international agreements and pertaining to Italy's relations with the European Union. As Capano and Guiliani (2003) report, 
$72 \%$ of successful government bills fall into one of these three categories over the period 19872002. In the remainder of this section, we discuss both the consensual features and circumventing tactics of the Italian parliament in greater detail.

\subsection{Consensual features}

During the so-called first republic (1946-92), each of the important parties in the Italian parliament wielded "de facto legislative veto power so that law-making became limited to those projects which were backed by ample [multi-party] supermajorities" (Capano and Giuliani 2001, p. 14; Di Palma 1976). Parliamentary rules undergirded this multilateral veto game, by making it very difficult to steer bills favored by narrow majorities through to a final passage vote. Rule 23 in particular required unanimity among group leaders to put a bill on the plenary agenda prior to 1997, and three-fourths thereafter. Although in 1981 the Speaker was given the right to propose an agenda, when the group leaders could not achieve the mandated level of consensus, the Speaker in the Chamber was generally not a member of the governing coalition after the 1960 sand thus the new powers of the Speakership were not reliably employed to push the government's agenda.

${ }^{1}$ Other rules provided minorities with further opportunities to delay. For example, amendments are largely unrestricted (and voted on in a successive procedure; see Rasch 1995; 2000), to the extent that it been reasonable to talk of an "amendment culture" (Cocozza 1989, 242). ${ }^{2}$ Indeed, some scholars view the Italian legislative agenda as largely chaotic and unpredictable (cf. Manzella 1974).

It is important to note, however, that the Italian government has never had difficulty in blocking bills from reaching the plenary agenda. The same rules that give the opposition the ability to block governmental proposals (e.g., Rule 23) also give the government the ability to 
block opposition proposals. The problem the government faced during the first republic, and continues to face during the second, is pushing its own bills onto the plenary agenda and through to a final passage vote, in the face of opposition. During both republics, the government's primary methods of pushing its agenda have involved circumventing, rather than working within, the ordinary statutory process.

\subsection{Circumventing tactics}

To begin with, we should note that Italian governments cannot usually use confidence in order to circumvent the scheduling roadblock posed by the Conference of Group Chairpersons. Parliamentary governments typically invoke confidence to ensure that their majority is cohesive on controversial matters (Huber 1996). In Italy, however, even a cohesive governing majority would typically fall short of the size — three-fourths of the assembly—needed to set the agenda. Thus, confidence is not usually an effective agenda-setting tool. (That being said, we control for whether the government has invoked confidence in assessing how the use of decrees and budget bills affect opposition and government roll rates.)

Another important circumventing tactic that Italian governments have used is to propose that parliament delegate to the executive the right to emit "legislative decrees" or make administrative rules in stipulated areas. Each such delegation requires an initial piece of authorizing legislation. However, after that, the government is largely free to pursue policies within the areas delegated. Capano and Giuliani $(2001 ; 2003)$ document the extensive and increasing use of such delegations.

Another important circumventing tactic—upon which we focus here—has been the Italian government's increasing use of emergency decrees (emitted under Article 77 of the Italian constitution). There have been two distinct sets of rules regulating the issuance of such 
decrees_-one before 1997 and one after. We describe each in turn. The main point of each discussion is to show that the government had better ability to push its agenda through the use (or abuse) of emergency decrees, followed by the introduction of a bill to convert the decree into law, ${ }^{3}$ than it had with ordinary bills. ${ }^{4}$

\subsubsection{The emergency decree game 1981-97}

The emergency decree game 1981-97 was a subtle and somewhat paradoxical one. To do it justice would require a full paper dedicated to it alone. However, the gist of the game was that the government could promulgate an emergency decree that had the immediate force of law. Upon issuing the decree, the government would immediately introduce a bill in parliament that sought to convert the decree into law. The Conference of Group Chairpersons could then either put the conversion bill on the plenary agenda for decision within 60 days, or not. If the conversion bill was not put on the agenda within 60 days, then the government could either allow the policy to revert to the original status quo, or it could reissue its decree. If the conversion bill was put on the agenda within 60 days, then one of three outcomes could ensue: (1) The parliament could pass the conversion bill unamended, thereby converting the government's decree into law. (2) The parliament could amend and then pass the conversion law, thereby changing the government's decree. Or, finally, (3) the parliament could specifically reject the conversion bill (and even reject the constitutionality of the underlying decree). Regardless of which of these three outcomes occurred—passage, amendment or rejection — the government could not then reissue its original decree.

We argue that the government's ability to push bills onto the agenda (and through to a final passage vote) was stronger for conversion bills than for ordinary bills. To explain this claim, note first that the government could reiterate its decree indefinitely, unless the Conference 
of Group Chairpersons agreed to put a conversion bill onto the plenary agenda (whereupon the bill might pass or fail, in either case preventing reissuance of the decree). Thus, the government could present the Conference with a choice between (a) agreeing to put the decree-conversion bill onto the plenary agenda and (b) enduring the indefinite reiteration of the decree. This is similar in many respects to the "take it or leave it" model of agenda setting discussed by Romer and Rosenthal (1978) except that in this case the government that is stacking the deck in the agenda process also holds a majority of seats in the Chamber of Deputies. In contrast, when the government introduced ordinary bills unrelated to any decree, the choice facing the Conference was between (a) agreeing to put the bill onto the plenary agenda and (b) the unperturbed continuation of the status quo.

How valuable was indefinite reiteration as a bargaining ploy for the government? There were certainly important limitations on the government's ability to change the status quo unilaterally by reiterating decrees indefinitely. First, prior to their conversion into law by the assembly, the governments' reiterated decrees had questionable legal status. Indeed, all decrees were supposed to be retroactively invalid if unconverted. But, if everyone knew that a decree had no chance of conversion, then everyone would believe that it would eventually become retroactively invalid and, hence, no one would rely on it to begin with. Thus, the only credible changes the government could implement via decree were those that had a reasonable chance of eventual approval by the assembly. Second, parliament could always choose to consider and reject a decree conversion bill, or even declare it unconstitutional. Thus, since conversion bills had to be put on the agenda, if the underlying decree was ever to escape the legal limbo of unconverted status, the government had a clear incentive to fashion decrees that could command a majority in the assembly. 
To illustrate, consider a simple unidimensional spatial model as illustrated in Figure 1 (Downs 1957; Black 1958; Shepsle 1979; and Shepsle and Weingast 1981, 1987). Keeping the majoritarian limitations on the government in mind, consider a situation in which a left-wing government decides to issue a decree that moves policy leftward from the status quo, q. Suppose that some right-wing opposition parties, constituting at least one-fourth of the assembly, have the following preference order: they prefer the status quo, q, to the policy that the Chamber median would choose, $\mathrm{C}$; and they prefer $\mathrm{C}$ to the indefinite reiteration of the government's decree. Whenever such a preference ranking exists for some opposition parties, their leaders in the Conference of Group Chairpersons have an incentive to allow consideration of the government's decree: they prefer $\mathrm{C}$, which they can get if they allow consideration, to indefinite reiteration, which is what they will get otherwise. ${ }^{5}$ In these cases, the government would fail to secure consideration of an ordinary bill seeking to change policy to $\mathrm{C}$ - because the Conference would block it and thereby preserve the status quo. However, by reiterating (or threatening to reiterate) a decree, the government might succeed in inducing the Conference to allow consideration of a conversion bill, leading ultimately to a change in policy from q to $\mathrm{C}$.

\section{Insert Figure 1}

Are there ever any situations of the kind we describe, in which opposition parties prefer $\mathrm{C}$ to indefinite reiteration? To see how such a situation might arise, suppose that the government's decree seeks to implement a policy—denote it by L—that is to the left of the Chamber median, C. The opposition does not need to believe that reiterating the decree will fully implement L, in the same way that converting the decree into law would. As long as they believe that reiterating the decree will de facto move policy far enough toward the government's target, they will prefer 
$\mathrm{C}$ to indefinite reiteration. In other words, as long as reiterated decrees are not discounted too much relative to converted decrees, the opposition may prefer $\mathrm{C}$ to indefinite reiteration. ${ }^{6}$

\subsubsection{The emergency decree game 1997-present}

In October 1996, the Italian Supreme Court ruled unconstitutional the reissuance of decree laws that "absent new and unexpected circumstances, substantially reproduce the content of a lapsed decree law" (Corte Costituzionale 1996). As a result, Rule 96-bis was amended in 1997 to make issuing an emergency decree in Italy more like a presidential urgency motion in Brazil. The emergency decree still had immediate legal effect, as the constitution stipulates. However, the re-issuance of decrees was outlawed, thereby removing one of the main tools the government had previously used to gain leverage in legislative bargaining. ${ }^{7}$ Compensating for this loss, however, new rules mandated that the bill to convert the decree into law should be given a fast progress through committee and onto the plenary agenda. It was then subject only to whatever delaying tactics the opposition could deploy in the plenary. As ordinary statutes faced not only floor delays but also considerable difficulty getting onto the floor to begin with, the government under the post-1997 rules still has been better able to push its policies via emergency decrees (followed by decree-conversion bills) than with ordinary bills. ${ }^{8}$

Thus, in both the 1981-97 and 1997-2000 periods, we expect to see the government better able to push conversion bills through to a final passage vote than it is able to push ordinary bills. Its greater ability to push (equivalently, the opposition's weaker ability to delay) should in turn mean that opposition parties' roll rates should be higher on conversion than ordinary bills. 


\subsection{Budget bills}

The procedures under which budget bills are considered in the Italian parliament have changed less dramatically than those governing decree conversion bills. For our purposes it suffices to note that, throughout the time period we investigate, the government has had clearly better powers to control the agenda on budget bills than on ordinary bills. In particular, rule 119(1) mandates a special 45-day session during which the government's budget bill must be considered and rule 119(7) mandates that a final passage vote on the budget bill must be held. Opposition parties thus cannot block the government's key budget bills from reaching a final passage vote.

\section{Cartel theory and roll rates}

In the introduction, we briefly characterized cartel theory (on which see Chandler, Cox and McCubbins 2006; Cox and McCubbins 2000, 2005, 2006; Cox, Kousser and McCubbins 2005; Cox, Masuyama and McCubbins 2000; Amorim Neto, Cox and McCubbins 2003; Cox, McCubbins and Skjaeveland 2007). In this section, we elaborate an argument from cartel theory that connects an assumption about the agenda-setting power of governing parties to observable implications about their roll rates. We call this the Cartel Agenda Model (CAM).

Let's begin with three assumptions. Ultimately, one only needs to believe that these assumptions are approximated but we will begin by stating them in their pure forms.

- (A1) Governing party leaders can correctly forecast when allowing a bill onto the plenary agenda would lead to a roll of their party.

- (A2) Each governing party can block any bill it wishes to.

- (A3) Governing parties never "trade rolls". 
The most important assumption — the one directly concerning agenda-setting power-is (A2). The other two assumptions concern how the posited agenda-setting power might be used. Together, the three assumptions are logically sufficient—but not necessary—-to predict that the average roll rate for governing parties will be nil. ${ }^{9}$

Are these assumptions plausibly approximated in the Italian case? Let's consider each in turn.

First, Assumption (A1) requires that governing parties be able to forecast whether a particular bill would lead to trouble for them in the plenary. We assume that the parties know the status quo, q, in the domain of policy that the bill addresses. The question is what the final version of the bill would be, after it had run the gantlet of amendments on the floor. If the bill deals with a single dimension of policy, the final version of the bill is easy to forecast-it will coincide with the floor median's ideal point (see Downs 1957; Black 1958).

A structural assumption embedded in the unidimensional spatial model crucial for the median voter result is that non-germane amendments (those that introduce a new dimension of policy) are not possible. Is this assumption plausible? In Italy, rule 89 provides some protection against non-germane amendments, as it enables the assembly president to declare unacceptable amendments that are "totally irrelevant." As regards decree conversion bills, rule 96-bis(7) allows the president to "declare as inadmissible any amendments and additional sections that are not strictly relevant to the subject of the decree-law." We take these rules as enough to largely protect governing parties from having to consider all possible non-germane amendments, thus simplifying their forecasting problem greatly.

Even if amendments in Italy do have to be germane to the subject of the original bill, there are still a lot of possible ones that might be offered. Moreover, in practice, many bills in 
Italy are considered under open rules and are subject to significant attempted and successful amendments. For these bills, forecasting the final version of the bill that will be pitted against the status quo in the final passage vote would presumably be quite difficult.

We stress, however, that there is a difference between the detailed content of a bill and its left-right location as represented in the spatial model. The same spatial location might be attained with many different contents. In the example of an "unemployment insurance dimension" running from more to less generous, the bill might be made more generous by easing the eligibility requirements, increasing the payouts, or extending the length of time benefits can be received-to name just three possibilities. Governments do not need to forecast these sorts of things. Nor do they need to forecast the precise package of side payments that might be embedded in a bill (which appears as noise in a unidimensional spatial model). They just need to forecast the spatial location. ${ }^{10}$

Second, assumption (A2) states that any governing party can veto any bill it wishes to. This is obviously an overstatement of the purely procedural powers of governing parties. If a governing (or opposition) party holds more than one-fourth of the parliament's seats, then it can use Rule 23 to unilaterally block a bill in the Conference of Group Chairpersons (although, even then, the speaker may put the bill on the agenda). ${ }^{11}$ But Rule 23 does not help governing parties that hold fewer than one-fourth of the seats.

(A2) also overstates the political powers of governing parties. A familiar idea in parliamentary studies (cf. Tsebelis 2002) is that each party in a coalition government has a veto over the agenda, sustained by its threat to exit the government. By threatening to exit, a pivotal governing party can force its partners to choose between (1) getting the bill the pivotal party is seeking to block but at the cost of having to form a new government; and (2) abandoning or 
modifying the bill the pivotal party is seeking to block, while continuing the government as presently constituted. Scholars have generally viewed the cost of forming a new government during the period of DC hegemony as low, in the sense that it entailed very little uncertainty about the political complexion of the next government: the DC was certain to continue in and dominate the next government, given the de facto ban on Communist participation in government. Thus, one might view the potency of threats to exit during this period as relatively low-leading to a larger discrepancy between the pure agenda veto envisioned by (A2) and Italian practice.

That being said, however, we would note three points. First, even during the period of DC hegemony, forming a new government entailed some risks for some parties and some individual politicians; and it also entailed the cost of negotiating the new government. While these are smaller costs than in other parliamentary cases (Mershon 2002), they are not nil, and so even in this period one might expect smaller governing partners to be able to influence the agenda. ${ }^{12}$ Second, as the Italian party system changed-with first a declining DC and then a new bipolar competitive format-exit threats should have become even more potent. Third, as long as governing parties were willing to carry through on their threats of exit, if unsuccessful in convincing their partners to abandon or modify an offensive bill, they will have thereby (a) avoided a roll as a governing party, while suffering one as an opposition party; and (b) have protected their reputation for carrying through on threats.

All told, it is clear that (A2) overstates the blocking power that governing parties had, either procedurally (via Rule 23) or politically (via threats to exit). Nonetheless, how far short of the idealized standard that (A2) sets out any particular case falls is less clear. And, in any case, (A2) merely states a sufficient condition to guarantee that governing parties will have nil roll 
rates, not a necessary condition. The empirical results that we present below suggest that governing parties were generally able to parlay their procedural and political cards into extremely low roll rates, whether by the effectiveness of their exit threats (convincing partners to abandon or modify bills) or through their willingness to exit government when their agendasetting desires were not respected.

Third, assumption (A3) states that parties do not trade rolls. That is, they do not engage in deals of the form "we'll allow bill A, which we know will roll us, if you allow bill B, which you know will roll you". We should stress that this assumption does not mean that governing parties cannot engage in ordinary logrolls. For example, an ordinary logroll between party A and party B in a two-party governing coalition would entail that both parties voted for each of two bills, one promoted by A and one promoted by B. This sort of vote trading would not result in either party being rolled, since a roll occurs only when a party votes against a bill that nonetheless passes. (A3) outlaws only a more specific form of trade, in which A allows B to put a bill on the agenda, which then passes although A votes against it, in return for B allowing A to do likewise. Violations of this assumption would not attack the core idea that majority governments form agenda cartels which distribute special agenda-setting privileges among governing parties; however, violations would lead to larger observed government roll rates.

We take assumptions (A1)-(A3) as approximately satisfied in Italy. We expect that the roll rate for governing parties will equal the rate at which such parties fail to anticipate the consequences of allowing bills onto the agenda; or threaten to exit government if a particular bill is allowed onto the plenary only to find their bluff called. We assume that governing parties are very good but not perfect at anticipating the spatial locations that bills will occupy when they reach a final passage vote; and we assume that governing parties are almost always either large 
enough to veto bills on their own or pivotal enough to secure the support of their partners. Thus, our first proposition is that we expect governing parties to have small but not necessarily nil roll rates. Regardless of the precise rate at which governing parties are rolled, we expect them to be rolled less often than opposition parties are on average.

Further, we make a prediction about the relationship between distance from the floor median, on one spatial dimension, and roll rates for government and opposition parties. Figure 2 displays the Cartel Agenda Model's predicted relationship between ideological distance and roll rates for government and opposition parties. The median of the governing coalition is marked by $\mathrm{M}$, the floor median by $\mathrm{F}$, and the median of the opposition parties by $\mathrm{m}$. The governing coalition will use its negative agenda power to prevent bills that roll the coalition from reaching a final passage vote, which leads to the prediction of no rolls in the block out zone between $2 \mathrm{M}-\mathrm{F}$ and $\mathrm{F}$. Extreme government parties or extreme members of governing parties may have a positive roll rate in the Cartel Agenda Model.

\section{Insert Figure 2 about here}

It is possible that there are variations over time in how well approximated these assumptions are in Italy. For example, perhaps forecasting votes correctly became easier under the new two-bloc party system that emerged after the DC's fall. However, we have no firm basis on which to expect any change in the "fit" of our assumptions over time and hence offer no predictions for cross-temporal change. Our focus remains on the cross-sectional differences we expect between government and opposition; and between the various different types of bill.

Our second proposition — that opposition parties' roll rates depend on their ability to delay—leads to two specific tests. First, as previous studies in other systems have found (e.g., Cox, Masuyama and McCubbins' study of Japan), we expect opposition parties' roll rates (but 
not government parties' roll rates) to increase as their ideal points diverge further from the legislative median. The logic of this prediction is that more extreme parties will more often find themselves in smaller opposing coalitions, and the smaller the opposing coalition is, the less able it will be to delay. As shown in Figure 2, we expect that opposition parties' roll rates will increase with distance from the floor median, hence the positively sloped line to the right of F. Consider, for example, a party with $10 \%$ of the seats - call it party A. If A is the median party, and politics is perfectly unidimensional, it will never be rolled-because no bill can pass against the wishes of the median in a perfectly unidimensional legislature. If, instead, A is the furthest left opposition party, then it may be the lone defender of some far-left status quo policies, in which case it will be rolled (as $90 \%$ suffices to overcome its delaying powers and pass a bill). Thus, the more extreme an opposition party is - as measured by the legislative quantile at which its ideal point is located — the more it will be rolled. ${ }^{13}$ A similar conclusion does not follow for government parties because the theory asserts that they are able to leverage their position in government and block bills that would roll them.

We further expect opposition parties' roll rates to be higher when the rules of procedure afford them less power to delay. The logic here is similar to that of Blondel (1973), except that he focused on the relationship between parliament and the executive, rather than (as here) the relationship between government and opposition. In the case of Italy, we can test this prediction by comparing opposition roll rates on decree conversion and budget bills (weaker opposition delay powers and thus higher predicted roll rates) and ordinary bills (stronger opposition delay powers).

We summarize our predictions in Table 1, noting in each case whether one would make the same prediction based on an alternative view in which (a) any coalition holding at least $1 / 4$ of 
the seats can block any legislation it wants; ${ }^{14}$ and (b) coalition discipline is weak, so parties within the governing and opposition coalitions vote as they choose, rather than toeing the coalitional line. Let's consider whether this alternative model, which we call the Floor Agenda Model (FAM) generates each of the five predictions derived from cartel theory.

\section{Table 1 about here.}

Under the Floor Agenda Model, a party with less than 1/4 can be rolled, unless it is the median party. Thus, small non-median governing parties can have arbitrarily large roll rates; in other words, the Floor Agenda Model does not predict that governing parties' roll rates will necessarily be very low. In Figure 3 we display the predicted roll rates that arise from the Floor Agenda Model. In the figure it is clear that governing parties will not necessarily have lower roll rates than opposition parties: in particular, a small non-median governing party may have a larger roll rate than a small non-median opposition party. Nor is it necessarily the case that opposition parties will be rolled less often on ordinary bills than on conversion/budget bills. The reverse could be true if ordinary bills happen to displease small opposition parties less often than do conversion/budget bills. All told, then, the only prediction that the Floor Agenda Model generates, among the four in Table 1, is the last.

\section{Insert Figure 3}

Would the Floor Agenda Model in which any coalition with at least 1/4 can block any bill, but both the government and opposition coalitions are cohesive, generate our predictions? Such a model would generate our first and last predictions but not our second or third. To see this, note that a cohesive opposition can be rolled only if it collectively holds less than $1 / 4$ of the seats. 
But in fact no governing majority in the period we study held over $3 / 4$ of the seats. Thus, a "cohesive coalitions" version of the Floor Agenda Model would predict that the opposition should have a nil roll rate, too, contra our second prediction. Moreover, the opposition roll rate on both ordinary and conversion/budget bills would be nil, so there would be no difference between the two, contra our third prediction.

\section{Data}

The Cartel Agenda Model of legislative policy making yields a number of testable hypotheses, not all of which are relevant to Italy. We test several that are relevant using an original dataset of voting in the Italian parliament that covers legislation from 1988, near the start of the Tenth Legislature (2 July 1987-2 February 1992), and ends in spring 2000, roughly one year before the mandated end of the Thirteenth Legislature on 9 March $2001 .^{15}$ This period includes ten governments ${ }^{16}$ that presided over final-passage votes on legislation (Amato's second government, beginning in April 2000, oversaw no final-passage votes in our time period).

Our data, which we obtained from the Italian parliamentary archives, are not unproblematic. One of the more vexing problems, the impermanence of parties, has more to do with the Italian political context at the end of the $20^{\text {th }}$ Century than with measurement per se. No party survived the entire time period covered by our data without a name change, and most parties that existed in the $10^{\text {th }}$ and $11^{\text {th }}$ legislatures were no longer on the scene during the $12^{\text {th }}$ and $13^{\text {th }}$ legislatures. This is not simply a case of party-system contraction: few parties that were active in the $12^{\text {th }}$ and $13^{\text {th }}$ legislatures had been present in the $10^{\text {th }}$ or $11^{\text {th }}$ legislatures either. Moreover, some parties do not even last an entire governing period. ${ }^{17}$ In what follows, we present roll rates only for those parties that existed at the beginning of the particular government under study. 
A second problem worth noting is the difficulty in matching the parties in our data set to parties in government. The problem here lies in how the data are reported: Italian governments are made up of electoral parties—-parties, that is, defined by their participation in elections through ballot lists. The parties in our data, by contrast, are defined not by participation in elections, but rather by the labels attached to parliamentary groups, which in turn are defined by and subject to legislative rules. ${ }^{18}$ Many electoral parties can and do form their own party groups. Others cannot, however, so some party groups are in essence coalitions of small parties or even of individual legislators who, for one reason or another, might choose to belong to groups different from their copartisans. Hence, while the "party" labels that define MPs' partisanship for purposes of legislative voting are in some sense "official"-we got them directly from parliamentary record keepers- - they sometimes are difficult to map into the labels used to define parties in government. ${ }^{19}$ Indeed, even large electoral parties that form their own party groups sometimes use a group name different from their electoral label, sometimes immediately and sometimes as a result of changing their group label in the course of the legislature.

Third, and partly as a consequence of the disjuncture between electoral parties and legislative party groups, there is no clear way to identify the ideal points of parliamentary groups other than by using their legislative voting patterns. Expert surveys, for example, and Manifesto data (Budge et al. 2001) concentrate on electoral parties, in essence rating parties on the basis of their electoral appeals. For the large parties that form their own parliamentary groups, such electorally grounded scores are reasonable; for groups that bring together legislators from different electoral parties, or that form from the fission of a larger party—as when the DC split into the CCD and PPI in the $11^{\text {th }}$ Legislature- these externally generated scores are either unavailable or irrelevant. ${ }^{20}$ 
Given that expert judgments cannot be used, we calculated party ideal points by tallying party members' votes and using them to calculate party positions. For this procedure, we began with base a dataset of over 2.9 million legislator-vote observations, including all final votes on legislation, all votes to convert decree laws, all votes where the relevant government minister and the relevant committee disagree on the advisability of passage, ${ }^{21}$ and all votes where the outcome goes against the responsible minister's recommendation (e.g., the vote was in favor but the government was opposed). ${ }^{22}$ These votes include article-by-article consideration of bills, as well as amendments and subamendments to bills or specific articles. Each deputy has six possible casts: aye, nay, "voted," abstain, absent, and "on mission" (absent with cause). We excluded all secret votes ("voted"), which reduced the data set to just over 1.68 million observations. If a majority of the party members who were present at a vote- that is, those who voted aye, voted nay, or abstained - voted for a proposition, then we counted the party as voting for the position. If a majority of the party members who were present at a vote voted against a proposition, then we counted the party as opposing the proposition. When neither the members voting nay nor the members voting aye constituted a majority of the party's present members-that is, when there were relatively large numbers of abstentions for a particular party on a particular vote-it is hard to be sure whether the party as a whole was for or against the proposition. We have tried various different rules to handle these cases and found that they all produce similar results. The particular results we report here handle abstentions in the way suggested by Prata (2006). ${ }^{23}$ Using these coding rules to identify each party's position on each roll call, we then (a) calculated party ideal points (via Poole 2000) using all available votes; and (b) calculated roll rates ${ }^{24}$, as is standard, using only final-passage votes. ${ }^{25}$ 
Our use of party ideal points and the distance between parties requires us to assume that Italian politics is one-dimensional, because our measure of ideological distance between parties is only meaningful along a single dimension. The advantage of making this assumption is that it allows us to test predictions about the relationship between distance from the floor median and roll rates for both government and oppositions. The possible downside of this assumption is that if our distance measure is highly flawed then these results will be meaningless. In general, our measures of ideological distance accord with the realities of Italian politics so we are reasonably sure that our distance measure is useful in this context. However, if one is skeptical about the distance measure, we present a variety of predictions and results that do not rely on our ability to measure distance between political parties (i.e. low government roll rates and opposition roll rates that are higher than the government's) and these results are not affected by our use of ideological locations computed from Optimal Classification. We turn now to a presentation of our results.

\section{Results}

\subsection{Government roll rates}

Our first two predictions entail that roll rates for government parties should be low and lower than roll rates for non-government parties. We test this prediction by comparing the average roll rates of government and non-government parties on all final passage votes (voto finale) in our dataset. The results are shown in Table 2.

Roll rates for government parties are quite low, averaging 0.5 percent. While greater than zero, this figure is comparable to government-party roll rates in Germany and a good deal lower than roll rates in a number of other parliamentary governments (Chandler, Cox, and McCubbins 2005). That government-party roll rates are not in fact zero seems reasonable, given the stringent 
informational assumption behind the prediction that government parties should never be rolled. Further, that parties in government sometimes are rolled does not necessarily imply that the government as a whole is rolled. Rather, the occasional government-party roll might be an indication of coalition leaders' ability to withstand defections on individual policy issues, either because they have built oversized coalitions in order to provide a safety net in case of defections, or because they can count on at least some opposition support in policy areas where some coalition partners want to defect (Dodd 1976; Luebbert 1986).

There is a large, statistically significant difference between roll rates for government versus non-government parties. ${ }^{26}$ The average roll rate for government parties is 0.005 and the average for opposition parties is 0.209 a difference that is significant at the 0.01 level in a twotailed t-test. Another test of the prediction that governing parties should have lower roll rates can be conducted by examining how a party's roll rate changes, when that party exits from government and there is not a change in the overall composition of the legislature. There are, not surprisingly, very few parties that exit government. Parties in government are loath to leave, as exiting would mean foregoing all the benefits of government office. Nonetheless, in the 12-year period for which we have data, we find five cases of parties exiting government during the course of a legislature: the Republican party in the $10^{\text {th }}$ Legislature, and the Northern League, Forza Italia, Christian Democratic Center, and National Alliance in the $12^{\text {th }}$ Legislature (the four cases in the $12^{\text {th }}$ Legislature all result from the formation of Dini's nonpartisan government). The movement from a partisan toward a non-partisan government likely understates the true significance of moving from in to out of government. While the data are intriguing we lack enough cases to perform a test of the effect of moving out of government. 
In Table 2, we display how much each party's roll rate increased, when it exited from government. Four of the five parties show an increase in their roll rates. The one party that doesn't have an increase in roll rate shows almost no change. Additionally, it is one of the parties that exits a partisan government that is in turn replaced by a nonpartisan government, which may explain why there are relatively small increases in roll rates for the four parties that exit government between the sixth and seventh government.

Table 2 about here

\subsection{Roll rates and distance from the floor median}

Our third prediction involves two claims. First, roll rates for opposition parties should increase with the distance from the party ideal point to the ideal point of the floor median. Second, distance from the floor median should have no effect on roll rates for government parties. Figure 4 illustrates party roll rates by distance from the floor median for opposition and government parties, respectively, for all governments except the nonpartisan government. ${ }^{27}$ The X-axis measures distance, in terms of NOMINATE scores, between a party's ideal point and the ideal point of the median party. The Y-axis measures a party's roll rate. Actual roll rates for the government and opposition parties are given by the dashed and solid line, respectively. As predicted, roll rates for non-government parties increase notably with distance from the floor median. Roll rates for government parties, by contrast, are quite low and basically invariant, in line with the expectations of the Cartel Agenda Model.

\section{Figure 4 about here}


Figure 5 shows the roll rate of government and opposition parties from the $13^{\text {th }}$ legislature. In the figure government parties are marked with a "G" and opposition parties are marked with an "N." The floor median is marked with an "F."

\section{Figure 5 about here}

In this example there are several government and opposition parties that are a nearly identical distance from the floor median (in the lower left corner of the figure). In all cases, the government parties have lower roll rates. Indeed, Figure 5 closely matches the predictions of the Cartel model for government and opposition parties. ${ }^{28}$

A more systematic method to investigate how distance from the legislative median affects a party's roll rate is to regress each party's roll rate on its distance. We have run such a regression separately for government and opposition parties. Our results indicate that a party's roll rate reacts about four times more to increases in its distance from the median when the party is in opposition, than when it is in government. ${ }^{29}$

The Cartel Agenda Model's predictions derive from the importance of negative agenda power and the results we present in this section are consistent with the government possessing significant negative agenda power. However, one might argue that these results could reflect party discipline on final passage votes rather than the ability to prevent legislation from reaching the final passage stage. To differentiate between the role of party discipline and negative agenda control we compare roll rates on amendment votes and final passage votes. If party discipline is the mechanism that generates low roll rates, then we should observe that the government is never rolled on either amendment votes or final passage votes. Alternatively, if negative agenda control 
is the mechanism that generates these low roll rates then we should observe that the government has positive roll rates on amendment votes and low (close to zero) roll rates on final passage votes. Prata (2006) reports that the Italian government is rolled on $26 \%$ of the amendment votes, which is significantly different than zero at the 0.01 level and that the government's roll rate on final passage votes is not significantly different than zero. These results are consistent with the importance of negative agenda control in generating the low government roll rates we observe, but are inconsistent with party discipline as the source of low roll rates.

The evidence here, as exemplified in Figures 1 and 2, conforms to the Cartel Agenda Model but not to the Floor Agenda Model. Our key test, on comparative statics across types of bills, is the topic to which we now turn.

\subsection{Opposition roll rates on ordinary, conversion and budget bills}

In this section we expand our analysis of party roll rates by considering roll rates on a variety of different types of votes, each of which has a different procedure for considering them in the legislature. This amounts to a non-equivalent dependent variables design (Trochim 2001) that increases our ability to draw causal inferences. Table 3 shows that the average roll rate for opposition parties, over the entire $1988-2000$ period, was $6.4 \%$ on ordinary bills, $28.9 \%$ on

decree conversion bills, and $64.1 \%$ on budget bills. ${ }^{30}$ The differences are both substantively and statistically significant. In contrast, the roll rate for governing parties is less than half a percent in all cases and literally zero on budget bills. None of these differences are statistically significant.

Table 3 about here 
The differences in opposition roll rates between ordinary, decree conversion and budget bills are only minimally affected by the government's use of confidence. Focusing on the $13^{\text {th }}$ legislature-where we could access comprehensive data—we found only nine instances in which the government invoked confidence on a legislative matter (as opposed to investiture and other procedural matters). In all nine cases, the bill under consideration was to convert a decree into law. The average roll rate for opposition parties on the 141 decrees that had no confidence attached was $22.0 \%$, versus $39.1 \%$ on the nine decrees to which the government attached confidence. Thus, although the government used confidence on some of the most controversial matters, there was still a substantially higher opposition roll rate, even on decree conversion bills that had no confidence attached.

To investigate the relationship between bill procedure and opposition roll rates more closely, we analyze the probability that opposition party $\mathrm{j}$ will be rolled on a final passage vote on bill $\mathrm{k}$. Our dependent variable is thus binary, equal to 1 if party $\mathrm{j}$ is rolled on bill $\mathrm{k}$, equal to zero otherwise. We run a separate probit equation for each government, including dummy variables for each opposition party. The dummy variables allow each party to have its own baseline roll rate, reflecting any fixed characteristics of that party during the government in question—such as its relative extremism or moderation vis-à-vis the other parties. The regressors of primary interest are Decree $_{\mathrm{k}}(=1$ if bill $\mathrm{k}$ is a decree conversion bill, 0 otherwise)

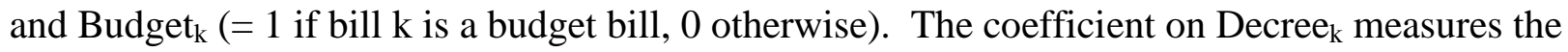
increase in a party's roll rate when the final passage vote concerns a decree bill (rather than the reference category of non-decree and non-budget bills); while the coefficient on Budget $\mathrm{k}_{\mathrm{k}}$ measures the increase in a party's roll rate when the final passage vote concerns a budget bill (rather than the reference category of non-decree and non-budget bills). 
Table 4 gives the results of our estimation for the first nine governments in our dataset (the tenth government had only 111 observations and none on budget bills—and hence we exclude it). The coefficients on Decree $_{\mathrm{k}}$ and Budget $\mathrm{k}_{\mathrm{k}}$ are both positive and significant in all governments, showing that opposition parties were more likely to be rolled on decree conversion and budget bills than on other bills, as we expected. The increased probability of a roll on decree conversion bills ranges from a low of .05 in Governo Berlusconi I to a high of .41 in Governo De Mita with a median probability increment of .15 . The increased probability of a roll on budget bills ranges from a low of .25 in Governo Prodi to a high of .79 in Governo Berlusconi I, with a median probability increment of .52 .

\section{Table 4 about here}

To the best of our knowledge, we are the first to measure the extent to which Italian governments have been able to push not simply more policies but also more controversial policies by using emergency decrees. The literature has emphasized that the government only succeeds in opening up a bargaining process, when it promulgates an emergency decree, and that it still has to make compromises (e.g., Della Sala and Kreppel 1998). We do not disagree with this. However, we do argue that the government has a better hand at the bargaining table, when it uses emergency decrees—and the data are consistent with this claim.

We also show that Italian governments, like governments in most other parliamentary settings, use the budget as their main tool to affect policy change. The budget process allows governments far greater control of the agenda than does the process for ordinary legislation 


\section{Conclusion}

How do governments push their bills through assemblies, against the delaying tactics of the opposition? In some cases, the answer is that the government has parliamentary rights that help it traverse the ordinary statutory process expeditiously. Examples of such powers include urgency motions (as in Brazil, on which see Amorim Neto, Cox and McCubbins 2003), special confidence powers (as in France, on which see Huber 1996), privileged ability to offer amendments (as discussed in Heller 2001), or the guillotine (as in the UK, on which see Dion 1997). In other cases, the rules of procedure leave the ordinary statutory process fraught with veto points but allow the government to circumvent the ordinary process, under certain circumstances. Examples of circumvention include delegation of decree powers and the creation of extraordinary budget procedures.

We argue that circumvention has been the key tactic for Italian governments during the period we study (1988-2000). Although the ability of Italian governments to control the ordinary legislative process improved in the later 1970s and 1980s, they still relied heavily on a variety of circumvention tactics in the 1990s and early 2000s (Capano and Giuliani 2001, 2003; Zucchini 2005). We have focused in this paper on their use of emergency decrees as permitted by Article 77 of the Italian constitution.

To clarify our point, we should note first that there is a big difference between the ability to block bills and the ability to push bills. Italian governments have never had great difficulty in blocking bills from reaching the plenary agenda. The same rules that provide veto power to the opposition also give the government blocking power. As we mentioned earlier, during the time period we analyze there was a change in Rule 23 that may have weakened opposition parties' negative agenda power and increased their roll rates. In unreported data analysis we find that the 
change in Rule 23 did not have a significant effect on opposition roll rates. ${ }^{31}$ Thus, it is not surprising to find, as we have documented here, that governing parties in Italy have very low roll rates. Indeed, depictions of it as uniquely chaotic notwithstanding, Italy's governing parties are forced to accept unwanted policy changes negligibly more frequently than are their counterparts in Germany and the UK.

Italy's parliament stands out from other assemblies because it gives opposition parties substantially more power to delay or block statutes. As we show here, a consequence of this generosity to minorities is that Italy's opposition parties have lower average roll rates. Where opposition roll rates in Germany and the UK average over $60 \%$, for example, the comparable figure in Italy is less than half (29\%).

Italy is again similar to other cases when one examines the determinants of opposition parties' roll rates. First, as has been documented in several other cases, more ideologically extreme opposition parties are rolled more often. Second, as has also been documented for other cases, opposition parties with better delaying powers are rolled less often. In Japan, the opposition is rolled less often on bills that pass through opposition-chaired committees (Cox, Masuyama and McCubbins 2000). In Germany, the opposition is rolled less often in the Bundestag when it has a majority in the Bundesrat (Chandler, Cox and McCubbins 2006). In Italy, we show that the opposition is rolled less often on ordinary bills (that must traverse the default legislative process) than on decree conversion and budget bills (that traverse a process giving the opposition weaker powers to delay and block). 


\section{References}

Allum, P.A. 1973. Italy: Republic without a Government? New York: Norton.

Amorim Neto, Octavio, Gary W. Cox, and Mathew D. McCubbins. 2003. "Agenda

Power in Brazil's Câmara dos Deputados, 1989 to 1998." World Politics 55(4): 550-578.

Amorim Neto, Octavio, and Fabiano Santos. 2001. “The Executive Connection: Presidentially

Defined Factions and Party Discipline in Brazil.” Party Politics 7:213-234.

Black, Duncan. 1958. The Theory of Committee and Elections. Cambridge, UK: Cambridge University Press.

Blondel, Jean. 1973. Comparative Legislatures. Englewood Cliffs, N.J.: Prentice-Hall.

Blondel, Jean. 1988. "Western European Cabinets in Comparative Perspective." In

Cabinets in Western Europe, edited by J. Blondel and F. Müller-Rommel, pp. 1-15.

London: Macmillan.

Budge, Ian, Hans-Dieter Klingemann, Andrea Volkens, Judith Bara, and Eric

Tannenbaum. 2001. Mapping Policy Preferences: Estimates for Parties, Electors and

Governments, 1945-1998. Oxford: Oxford University Press.

Camera dei Deputati. 2003. Regolamento della Camera dei Deputati Camera dei Deputati, 2003

[cited September 16 2003]. Available from

http://www.camera.it/index.asp?content=\%2Fdeputati\%2Ffunzionamento $\% 2$ F05

$\% 2$ Eregolamento $\% 2$ Easp.

Capano, Giliberto, and Marco Giuliani. 2001. "Governing Without Surviving? An

Italian Paradox: Law-Making in Italy, 1987-2001." Journal of Legislative Studies 7(4):13-36.

Capano, Giliberto, and Marco Giuliani. 2003. "The Italian Parliament: In Search of a 
New Role?" Journal of Legislative Studies 9(3):8-34.

Chandler, William, Gary W. Cox, and Mathew D. McCubbins. 2005. “Agenda

Control in the German Bundestag, 1980-2002". German Politics 15(1):27-48.

Cocozza, Francesco. 1989. Il Governo nel Procedimento Legislativo. Milan: Dott. A. Giuffrè.

Corte Costituzionale della Repubblica italiana. 1996. Sentenza 360/1996, Gazzeta Ufficiale della Repubblica italiana, 30 October 1996.

Cotta, Maurizio. 1990. "The Centrality of Parliament." In Parliament and Democratic Consolidation in Southern Europe, edited by M. Cotta and U. Liebert, pp. 249-272. London and New York: Printer Publishers.

Cox, Gary W. 1987. The Efficient Secret: The Cabinet and the Development of Political Parties in Victorian England. Cambridge: Cambridge University Press.

Cox, Gary W., and Mathew D. McCubbins. 2005. Setting the Agenda

Cox, Gary W., and Mathew D. McCubbins. 2006. Legislative Leviathan: Party Government in the House, $2^{\text {nd }}$ edition. Cambridge: Cambridge University Press. Cox, Gary, Mathew McCubbins, and Mikitaka Masuyama. 2000. "Agenda Power in the Japanese House of Representatives." Japanese Journal of Political Science 1: 1-21

Gary W. Cox, Thad Kousser and Mathew D. McCubbins 2005. "What Polarizes Parties? Preferences and Agenda Control in American State Legislatures." Paper presented at the 2005 APSA Meeting, Washington D.C.

Gary W. Cox, Mathew D. McCubbins, and Asbjorn Skjaeveland. 2007. "Agenda Power and Lawmaking in the Danish Folketing” Working Paper.

Della Sala, Vincent, and Amie Kreppel. 1998. "Dancing Without a Lead: Legislative 
Decrees in Italy." In Executive Decree Authority, J. Carey and M. Shugart, pp. 175-196. Cambridge: Cambridge University Press.

Di Palma, Giuseppe. 1976. "Institutional Rules and Legislative Outcomes in the Italian Parliament." Legislative Studies Quarterly 1:147-179.

Dion, Douglas. 1997. Turning the Legislative Thumbscrew : Minority Rights and Procedural Change in Legislative Politics. Ann Arbor, M.I.: University of Michigan Press.

Dodd, Lawrence C. 1976. Coalitions in Parliamentary Government. Princeton, N.J.: Princeton University Press.

Downs, Anthony. 1957. An Economic Theory of Democracy. New York: Harper.

Ferrara, Federico, 2004, "Frogs, Mice and Mixed Electoral Institutions: Party Discipline in Italy's XIV Chamber of Deputies." The Journal of Legislative Studies.10(4):10-31

Furlong, Paul. 1990. "Parliament in Italian Politics." West European Politics 13:52-67.

Heller, William B. 2001. "Making Policy Stick: Why the Government Gets What It Wants in Multiparty Parliaments." American Journal of Political Science 45(4):780-798.

Heller, William B., and Carol Mershon. 2003. "Switching in Parliamentary Parties: Exits and Entries in Parliamentary Groups in the Italian Chamber of Deptuties, 1996-2001." Unpublished manuscript, University of Virginia.

Hine, David. 1993. Governing Italy: The Politics of Bargained Pluralism. Oxford: Clarendon Press.

Hine, David, and Renato Finocchi. 1991. "The Italian Prime Minister." West European Politics 14:79-96.

Huber, John D. 1996. Rationalizing Parliament: Legislative Institutions and Party Politics in France. Cambridge and New York: Cambridge University Press. 
Kiewiet, D. Roderick and Mathew D. McCubbins. 1991. The Logic of Delegation:

Congressional Parties and the Appropriations Process. Chicago: University of Chicago Press.

Luebbert, Gregory. 1986. Comparative Democracy: Policy-Making and Government Coalitions in Europe and Israel. New York: Columbia University Press.

Manzella, Andrea. 1977. Il Parlamento. Bologna: Il Mulino.

Manzella, Andrea. 1991. Il Parlamento, 2nd edition. Bologna: Il Mulino.

Mershon, Carol. 2002. The Costs of Coalition. Stanford, C.A.: Stanford University Press.

Poole, Keith T. 2000. "Non-Parametric Unfolding of Binary Choice Data." Political Analysis 8 (2):211-237.

Prata, Adriana. 2006. “Government Domination, Consensus or Chaos? A Study of Party Discipline and Agenda Control in National Legislatures”. Doctoral Dissertation in Political Science, University of California San Diego, accepted December 2006.

Rasch, Bjørn Eric. 1995. "Parliamentary Voting Procedures." In Parliaments and Majority Rule in Western Europe, edited by H. Döring, pp. 488-527. Frankfurt and New York: Campus Verlag and St. Martin's Press.

Rasch, Bjørn Eric. 2000. "Parliamentary Floor Voting Procedures and Agenda Setting in Europe." Legislative Studies Quarterly 25:3-23.

Romer, Thomas and Rosenthal, Howard. (1978). "Political resource allocation, controlled agendas and the status quo." Public Choice 33(4): 27-43.

Schwartz, Thomas. 2006. "Parliamentary Procedure: Principal Forms and Political Effects.” Working Paper. Presented at UC San Diego December 12, 2006. 
Shepsle, Kenneth. 1979. "Institutional Arrangements and Equilibrium in Multidimensional Voting Modes." American Journal of Political Science 23: 27-59

Shepsle, Kenneth and Barry Weingast. 1981. "Structure Induced Equilibrium in Multidimensional Voting Models." American Journal of Political Science 37: 509-19 . 1987. "The Institutional Foundations of Committee

Power." American Political Science Review 81: 85-104.

Spotts, Frederic, and Theodor Wieser. 1986. Italy: A Difficult Democracy. Cambridge: Cambridge University Press.

Trochim, William. 2001. The Research Methods Knowledge Base. Cincinnati: atomicdogpublishing.

Tsebelis, George. 2002. Veto Players: How Political Institutions Work. New York and Princeton: Russell Sage Foundation and Princeton University Press.

Weingast, Barry R. 1992. "Fighting Fire with Fire: Amending Activity and Institutional Change in the Postreform Congress." In The Postreform Congress, edited by R. H. Davidson. New York: St. Martin's Press.

Zucchini, Francesco. 2005. "The Legislative Agenda Setting Power in a Changing Parliamentary Democracy: the Italian Puzzle." Unpublished typescript, Università degli studi di Milano. 
Table 1: Some predictions from the Cartel Agenda Model and the Floor Agenda Model

\begin{tabular}{|l|l|l||}
\hline Prediction & $\begin{array}{l}\text { Does Cartel Agenda } \\
\text { Model make this } \\
\text { prediction? }\end{array}$ & $\begin{array}{l}\text { Does Floor Agenda } \\
\text { Model make this } \\
\text { prediction? }\end{array}$ \\
\hline Governing parties' roll rates will be very low. & Yes & No \\
\hline $\begin{array}{l}\text { Governing parties' roll rates will be lower than } \\
\text { opposition parties'. }\end{array}$ & Yes & No \\
\hline $\begin{array}{l}\text { Opposition parties will be rolled less often on } \\
\text { ordinary bills than on conversion/budget bills. }\end{array}$ & Yes & No \\
\hline $\begin{array}{l}\text { An opposition party's roll rate increases as its } \\
\text { ideological location becomes more extreme. }\end{array}$ & Yes & Yes \\
\hline $\begin{array}{l}\text { A governing party's roll rate is largely unaffected } \\
\text { as its ideological location becomes more extreme }\end{array}$ & Yes & No \\
\hline
\end{tabular}


Table 2: Increase in roll rates for parties that exit government during a legislature

\begin{tabular}{||l|l|l|l||}
\hline PARTY & $\begin{array}{l}\text { ROLL RATE IN } \\
\text { GOVERNMENT }\end{array}$ & $\begin{array}{l}\text { ROLL RATE } \\
\text { OUT OF } \\
\text { GOVERNMENT }\end{array}$ & $\begin{array}{l}\text { CHANGE } \\
\text { IN ROLL } \\
\text { RATE }\end{array}$ \\
\hline Republican & .021 & .156 & .135 \\
\hline $\begin{array}{l}\text { Northern } \\
\text { League }\end{array}$ & .007 & .037 & .03 \\
\hline $\begin{array}{l}\text { Christian } \\
\text { Democratic } \\
\text { Center }\end{array}$ & 0 & .031 & .031 \\
\hline Forza Italia & 0 & .031 & .031 \\
\hline $\begin{array}{l}\text { National } \\
\text { Alliance }\end{array}$ & .007 & 0 & -.007 \\
\hline
\end{tabular}

Note: The National Alliance changed its name from AN-MSI to AN shortly after Berlusconi's first government was replaced by Dini's nonpartisan government. It participated in only seven votes under the AN-MSI label. We have combined the roll rates for the AN-MSI and the AN in this table.

Table 3: How roll rates differ on ordinary, decree conversion and budget bills

\begin{tabular}{||l|l|l||}
\hline ROLL RATE ON... & GOVERNING PARTY & OPPOSITION PARTY \\
\hline Ordinary bills & $0.5 \%(2666)$ & $6.4 \%(4313)$ \\
\hline Decree conversion bills & $0.2 \%(1992)$ & $28.9 \%(3635)$ \\
\hline Budget bills & $0.0 \%(150)$ & $64.1 \%(209)$ \\
\hline
\end{tabular}

Note: Of 2666 observations of a governing party voting on an ordinary bill, $0.5 \%$ resulted in a roll of that party. We excluded 284 bills whose type (ordinary, decree conversion, budget) we could not ascertain. Including these bills changes the results only slightly. We also exclude Governo Dini, a non-partisan government, from analysis. 
Table 4: Probability that an opposition party is rolled, by type of bill

\begin{tabular}{|l|l|l|l|}
\hline Government number & $\begin{array}{l}\text { Estimated increase } \\
\text { in probability of a } \\
\text { roll on decree } \\
\text { conversion bills }\end{array}$ & $\begin{array}{l}\text { Estimated increase } \\
\text { in probability of a } \\
\text { roll on budget bills }\end{array}$ & $\begin{array}{l}\text { Pseudo-R }{ }^{2} \text { (Number } \\
\text { of observations) }\end{array}$ \\
\hline 1 & .41 & .79 & $.27(1004)$ \\
\hline 2 & .26 & .75 & $.21(1606)$ \\
\hline 3 & .28 & .52 & $.13(906)$ \\
\hline 4 & .11 & .47 & $.11(947)$ \\
\hline 5 & .06 & .47 & $.08(1758)$ \\
\hline 6 & .05 & .50 & $.21(565)$ \\
\hline 8 & .23 & .25 & $.17(1939)$ \\
\hline 9 & .15 & .62 & $.16(874)$ \\
\hline
\end{tabular}

Note: We excluded 284 bills whose type (ordinary, decree conversion, budget) we could not ascertain. Including these bills changes the results only slightly. We also exclude Governo Dini, a non-partisan government, from analysis. 
Figure 1: Impact of Decrees on Policy Outcomes

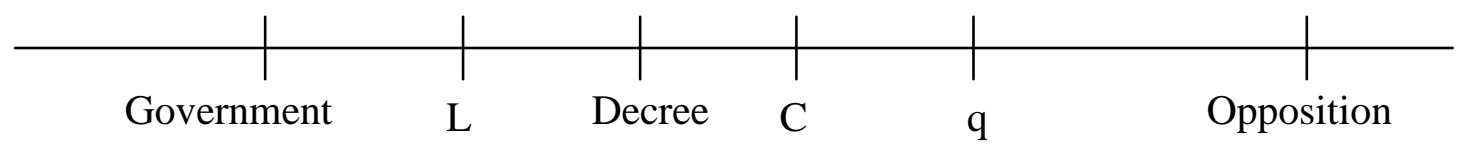


Figure 2: Cartel Agenda Model and Predicted Roll Rates

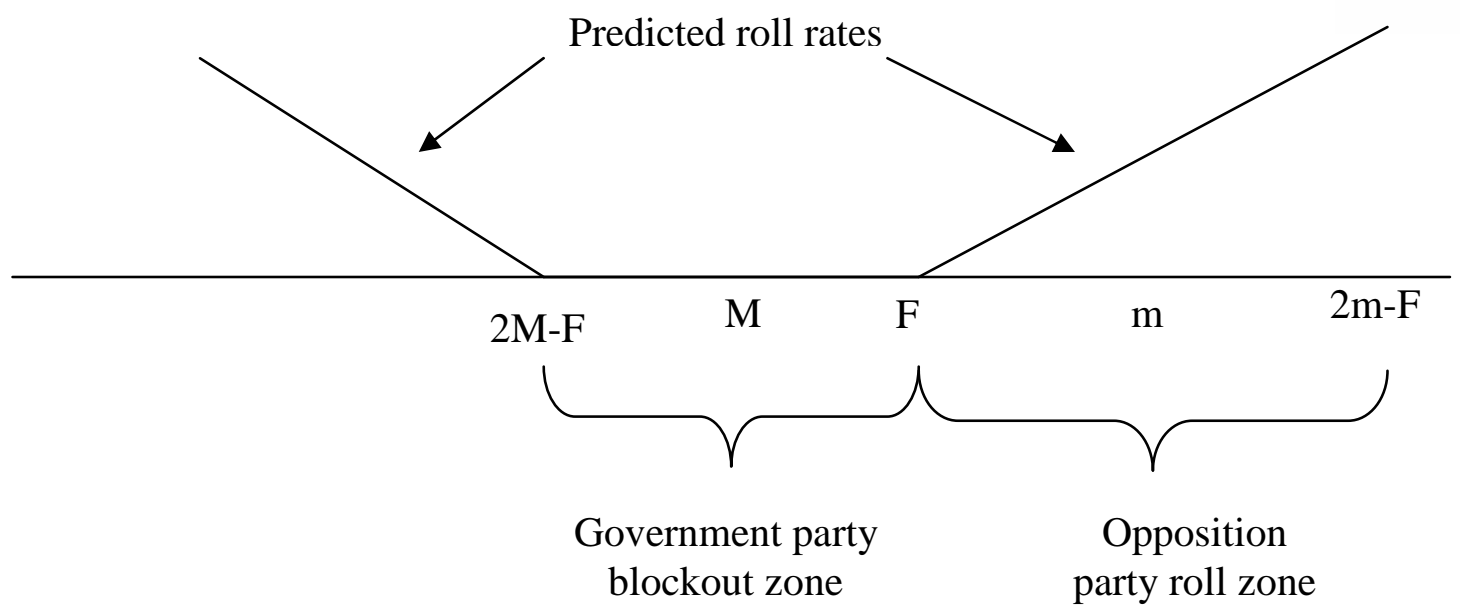


Figure 3: Floor Agenda Model and Predicted Roll Rates

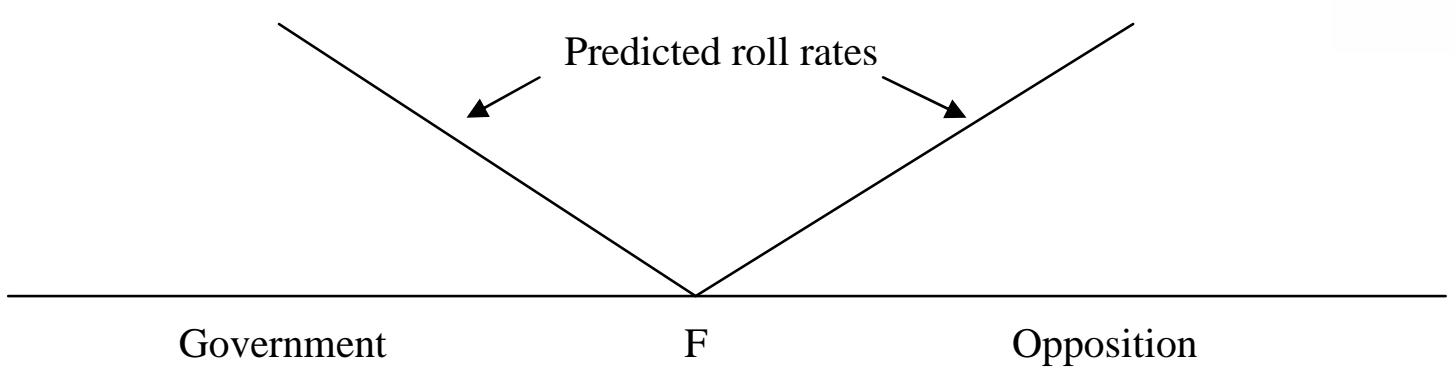


Figure 4: Roll rates for government and non-government parties by distance from the floor median

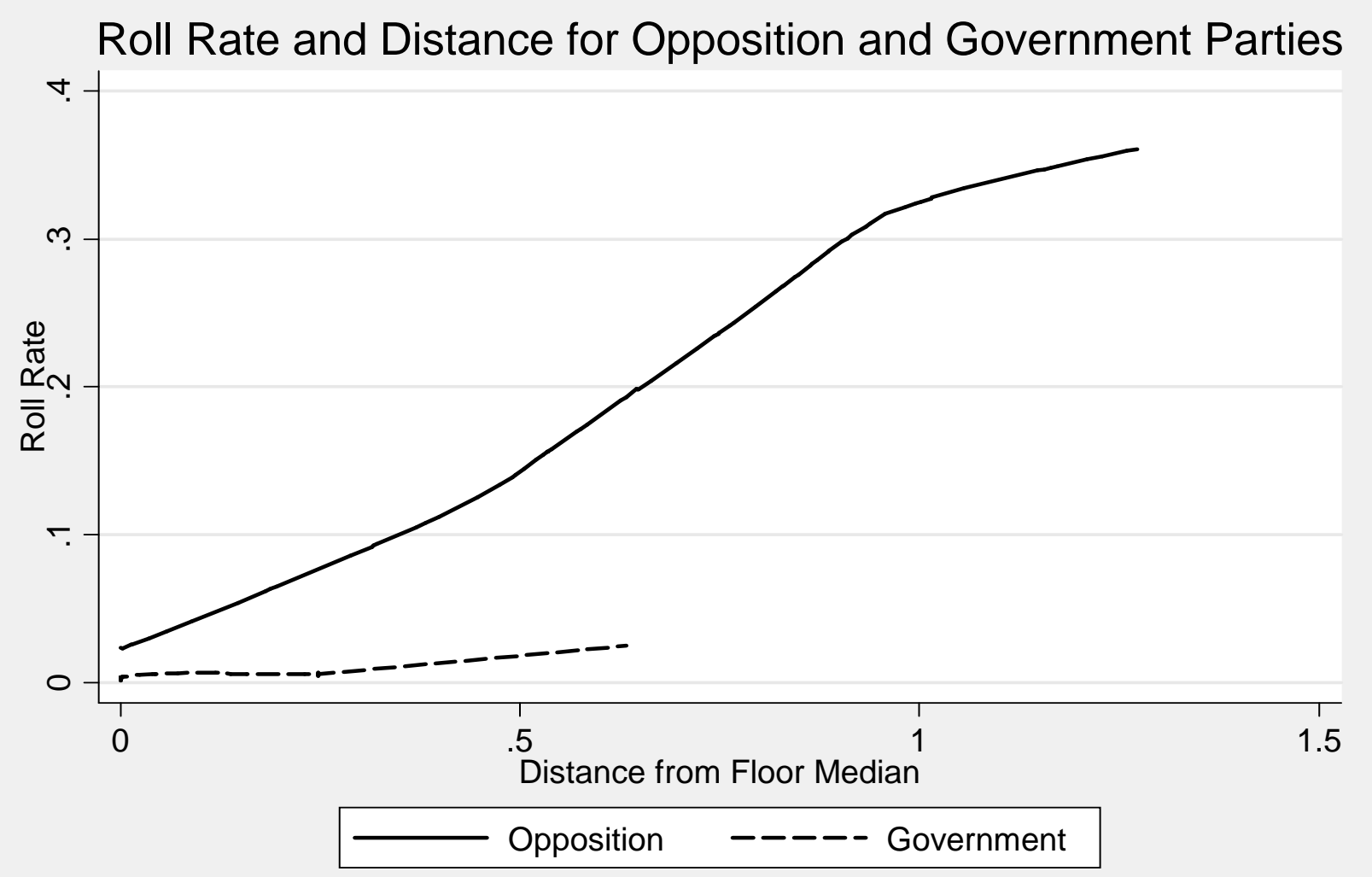


Figure 5: Party roll rates, Prodi, May 1996-October $1998\left(13^{\text {th }}\right.$ Legislature $)$

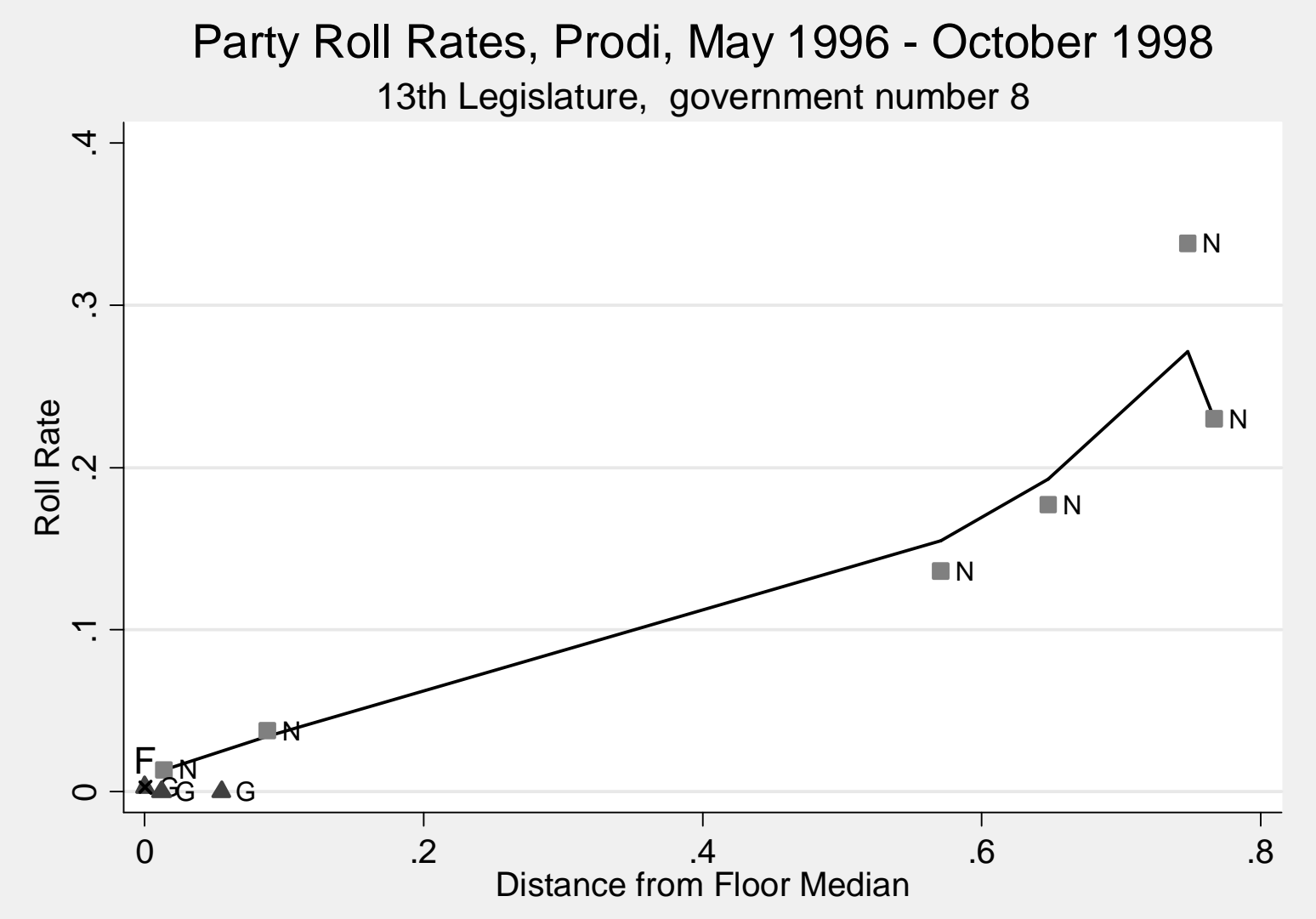

Distance was computed using Optimal Classification with abstentions counted as missing. An "F" represents the party that occupies the floor median, a "G" represents a party in the government, and a "N" signifies a non-government party. 


\section{Author information}

Gary W. Cox is Distinguished Professor of Political Science at University of California, San Diego.

William Heller is Assistant Professor of Political Science at Binghamton University.

Mathew D. McCubbins is Distinguished Professor of Political Science at University of California, San Diego. 


\title{
Endnotes
}

\begin{abstract}
${ }^{1}$ Indeed, during the period from 1968 to 1992, the Speaker was a member of the governing coalition less than $10 \%$ of the time. In contrast, during the period of strongest DC hegemony, 1948 to 1968, the Speaker was always a member of the government.

${ }^{2}$ Cocozza (1989) claims that the government's power to present amendments, subamendments, and additional sections up to the final vote on an article allows it to correct problems created by unexpected votes. Heller (2001; see also, Weingast 1992) looks at the same procedure and sees a government ability to threaten defectors from the erstwhile majority fold with policy losses if they fail to support the government. This "last offer" power (Heller 2001) has been successively diluted in changes to article 86 of the legislative rules in 1986, 1997, and 1999
\end{abstract} (Camera dei Deputati 2003).

${ }^{3}$ For short-term measures designed to confront actual emergencies, the question of convertibility is irrelevant.

${ }^{4}$ By an ordinary bill we mean one that neither converts an emergency decree into law nor deals with Italy's relations with the EU nor deals with the budget. The latter two types of bill_EU and budget—also had special rules that advantaged the government.

${ }^{5}$ It is an open question to what extent the members of the Conference of Group Chairpersons are loyal agents of their respective parties. In the U.S. context Kiewiet and McCubbins (1991) and Cox and McCubbins (1993; 2005) explore this question at length. It would seem like a relevant question to study in the Italian context, too.

${ }^{6}$ It has also been suggested to us that reiterating decrees allows governing parties to continue bargaining among themselves. This may well be but it does not affect our central point.

7 Zucchini (2005) points out that the government's bargaining position may even have been strengthened by its loss of ability to reissue decrees. The argument is that, when the government could reissue, the assembly could refuse to consider a conversion bill, and thus give itself time to bargain and to prepare amendments. When the government could no longer reissue, then-assuming that the assembly often had insufficient time to prepare amendments-it could make a take-it-or-leave-it offer to the assembly. If Zucchini is correct about this, then the main point we state in the text-that the government was in a better position using decrees and conversion bills than using ordinary bills - is further strengthened.

${ }^{8}$ We note two other points about the post-1997 regime. First, Zucchini (2005) suggests that the faster procedure for conversion bills, combined with the possibility of adding not-very-germane amendments to them, means that they can be freighted with goodies to form large supporting majorities. This is another advantage of the procedure-it suggests the government may be able to buy a just-large-enough majority to ensure that the conversion bill has a reasonably speedy processing on the floor, thereby enabling it to roll somewhat larger portions of the opposition than would otherwise be possible. Second, the 1997 rule changes also required the government to explain why there was an "emergency" that justified its use of emergency decrees. This new requirement does not seem to have had a large practical impact, in the sense that the government has continued to emit a large number of such decrees.

${ }^{9}$ There are two different types of final passage vote in the world's assemblies but our proposition works for either (see Schwartz 2006 for a discussion of the different types of final passage votes). One type is that used in the US House, where the last vote is that which pits the bill (as-amended, if amended) against the status quo. Another type is that used in Argentina and Mexico, in which the vote for a bill against the status quo occurs first, followed by a number of votes on amendments. Given (A1)-(A3), these two different sequences yield identical predictions about government roll rates.

${ }^{10}$ For those readers who, as we do, believe the world to be inherently multidimensional, we would make two points. First, most of cartel theory's predictions do not require an assumption of unidimensionality (cf. Cox and McCubbins 2005). Second, even though multidimensional scaling algorithms, such as NOMINATE, routinely find a single dominant dimension of political contestation in most assemblies, this does not require one to believe that the world is in some narrow technical sense unidimensional. The standard "two space" theory, reviewed by Poole (2005, ch. 1), allows one to believe that the real world is composed of many individual issue dimensions that exhibit significant inter-issue constraints, producing the appearance of (and, for predictive purposes, the reality of) a single dimension.

${ }^{11}$ We do not know how often the speaker puts items on the agenda. We have found several cases in the current $\left(15^{\text {th }}\right)$ legislature (well after our data end) where the legislative agenda is set according to article 24, paragraph 3 of the chamber rules--that is, "If the majority as set out in paragraph 2 is not obtained in the Conference of Group Chairpersons, the order of business shall be drawn up by the President of the Chamber. We have also found one case 
in the 14th legislature (also beyond our dataset). We are only able to search the legislative records from the $14^{\text {th }}$ and $15^{\text {th }}$ legislatures and we cannot determine if the search criteria we used recovered all of the instances of the speaker determining the agenda.

${ }^{12}$ We might add that even surplus parties may be able to threaten exit with some impact. It is true that their exit will not deprive the government of a majority but it will at least mean that whatever reason induced the government to include them in the first place - to clear a super-majority hurdle, to establish credibility in some policy area, to secure a workable majority in the upper chamber-will no longer be served.

${ }_{13}$ This proposition would not hold, of course, in a legislature that had a binding unanimity requirement. More generally, larger supermajority requirements mean that increasingly extreme parties are increasingly protected from rolls.

${ }^{14}$ There are 630 seats in the Chamber of Deputies, so a party or coalition with at least 157 seats would be able to block legislation. There are only nine individual parties in our dataset that hold at least $25 \%$ of the seats in parliament. During the Berlusconi I government an opposition party - Progressive Alliance Federation - holds more than $25 \%$ of the seats, which is the only time an opposition party holds that many seats.

${ }^{15}$ Our data on final passage votes were collected from electronic files at the Camera dei Diputati in the week of 19 June 2000. With the assistance of parliamentary staffer Ing. Alessandro Ghittoni, one of the authors queried the parliamentary database "Banche Dati delle votazioni elettroniche in Aula" for all final votes on bills (combining records for roll-call and secret votes-votazione palese nominale finale and votazione segreta finale) from 1988 to June 2000. The starting point 1988 was chosen because it was in that year that the parliament changed its rules to limit the number of secret votes on bills. Prior to 13 October 1988, most votes in parliament were secret, but since 1988 , secret voting is allowed only on votes concerning individual deputies and a limited range of other issues (Regolamento, art. 49). This inquiry yielded a total of 1802 votes, of which 1681 were final-passage votes. Of the final passage votes we were able to determine if they were budget, decree or ordinary bills. To our knowledge, the only similar data on the Italian parliament is from Ferrara (2004, p. 19) who collected "5,692 electronically recorded votes cast by Italian members of parliament between June 2001 and May 2002." Ferrara entered data from .pdf files that he got from the Chamber website; as far as we can tell, those files are no longer available.

${ }^{16}$ Our data cover ten governments, beginning in the middle of the De Mita government in 1988 and ending in 2000 with D'Alema's second government. We excluded analysis of the $7^{\text {th }}$ government (Dini's government of independents), because it was a non-partisan government without a majority party or coalition. Thus, we could not compare roll rates of governing and opposition parties.

${ }^{17}$ For a detailed presentation of party shifts and name changes in the 13th Legislature, see Heller and Mershon 2003, Appendix A.

${ }^{18}$ For example, while all members of parliament must belong to a parliamentary group, the minimum number of members that a group can have is twenty. When a group's membership falls below 20 , parliamentary rules require that its members either join some other group or be relegated to the catch-all (and hence ideologically undefinable) gruppo misto (Mixed Group).

${ }^{19}$ It is worth noting as well that the difficulties in identifying parties are not confined to government membership. Our data give us acronyms, not full group labels, and it can sometimes be surprisingly difficult to identify the correspondence between acronyms and parties or even parliamentary party groups: party names change, party group names change, different sources use different acronyms for the same party, parties merge, and it can be difficult to find solid information about party groups with lifespans shorter than an entire legislature. Further, some so-called party groups identified in the $10^{\text {th }}$ and $11^{\text {th }}$ legislatures are in fact subgroups of the Mixed Group that are not separately identified in the $12^{\text {th }}$ and $13^{\text {th }}$ legislatures. We have coded data of which we are uncertain as "missing."

${ }^{20}$ As a side note, the Manifesto Project scores often do not jibe with expert judgments on Italian parties, a problem we also have seen in the data on Japanese parties. We did not find this to be problematic in our study of Germany (Chandler, Cox and McCubbins 2005).

${ }^{21}$ This disagreement, as well as the responsible minister's recommendation, is observable only on nonfinal votes.

${ }^{22}$ Data selection criteria were determined in the Camera dei deputati's servizio parlamentare. We were unable to obtain data on non-final votes where government and the relevant committee recommendations agreed and the outcome jibed with the government's stated preferences.

${ }^{23}$ Prata (2006) counts a party as opposing a motion if the number of nay votes exceeds the number of abstentions and also exceeds the number of aye votes. She counts a party as favoring a motion if the number of aye votes exceeds the number of abstentions and also exceeds the number of nay votes. Finally, she codes the party position as missing (unverifiable) if neither of the above conditions is satisfied. 
${ }^{24}$ Roll rates are defined as the total number of times a party is rolled divided by the total number of final passage votes for a party (see Cox and McCubbins 2000; 2005; 2006; Cox, Kousser and McCubbins 2005; Amorim Neto, Cox and McCubbins 2003; Cox, Masuyama and McCubbins 2000)

${ }^{25}$ The sample of votes that we utilize to calculate roll rates is a subset of the votes on which we calculate party's ideological location.

${ }^{26}$ It is worth noting that the average roll rate for non-government parties is low, at least when compared to an average opposition roll rate of $72 \%$ in Germany, for example (see Chandler, Cox, and McCubbins 2005, 23).

${ }^{27}$ We computed Optimal classification using two dimensions, and then used the first dimension to calculate distance from the floor median, which is defined as the absolute value of distance between a party and the median party on that first dimension. According to Poole (2006) using optimal classification in two dimensions allows us to recover interval level data.

${ }^{28}$ Figures for other governments are available at www.settingtheagenda.com

${ }^{29}$ Using extended beta-binomial regression, the estimated probability of a roll for a government party located .5 units from the legislative median (which was near the maximum distance for any government party and the average distance for all parties) was .022, versus .003 for a government party located at the legislative median. Thus, moving from 0 to .5 units away from the legislative median increased a typical government party's estimated roll rate by .019. The comparable figure for an opposition party was an estimate roll rate of .084, or 4.4 times larger. The regression results and corresponding data set are available at www.settingtheagenda.com.

${ }^{30}$ We classified each bill in our dataset into one of four categories: decree conversion, budget, other, and missing. We exclude the bills for which we cannot ascertain the type from analysis.

${ }^{31}$ These results are available at settingtheagenda.com 